\title{
THE RELATIONSHIP BETWEEN METACOGNITION SKILLS WITH THE STUDENT'S ACHIEVEMENT: THE IMPLEMENTATION OF READING-CONCEPT MAP-THINK PAIR SHARE (REMAPTPS) MODEL
}

\author{
Linda Tri Antika \\ ${ }^{1}$ Universitas Islam Madura \\ Pamekasan, 69363, Indonesia \\ lindatriantika@gmail.com
}

\begin{abstract}
The aims of this research were: 1) to explain the correlation of metacognitive skills and student's achievement taught using Reading-Concept Map-Think Pair Share; and 2) to explain contribution of metacognitive skills to student's achievement. This study used correlational research design. Subjects of this research were the $10^{\text {th }}$ grade MIA-2 students at SMAN 2 Malang. This study was done in one semester. The results of the study showed that: 1) there was a significant correlation of metacognitive skills and students achievement; and 2) the contribution of metacognitive skills to student's achievement was 79,6\%.
\end{abstract}

Keywords: Students achievement, metacognitive skills, Reading-Concept Map-Think Pair Share 


\section{Introduction}

The test results and the evaluation of PISA for material science, reading, and mathematics showed that Indonesia still belongs to the students. Average consecutive score achievement students Indonesia to science, reading, and mathematics is ranked 62, 61, and 63 from 69 countries are evaluated. Ratings and an average score of Indonesia did not vary much with the test results and a survey of PISA earlier in the year 2012 which also are in the Group of the low material mastery. The results of these assignments for all citizens of Indonesia to jointly improve the quality of education, one of which is to enhance the skills of metacognition.

Metacognition is a term introduced by Flavell in 1976. Flavel stated that Metacognition means the ability to think about how his studies. Through the ability to think of how learning can be obtained information how the success of their learning so that it can be improved to further learning. Arends (2011) tells us that Metacognition is a process of knowing and monitoring the process of cognitive or thinking for yourself. Added by Peters (2000) that Metacognition refers to the conscious pupils skills and monitor the process of analytical study. Slavin (2011) mention of Metacognition is knowledge of learning; how he learned and how it monitors the way learning is done.

Dawson (2008:3) explains that the skill set of competencies is Metacognition are related to learning and thinking, as well as the skills needed for active learning, critical thinking, reflective judgments, problem solving, and decision making. Email (2002:3) stated that the skills of Metacognition is extremely necessary for the success of learning, Metacognition skills considering allowing students to be able to manage the cognitive skills and being able to see his weaknesses, so that it can carried out repairs on the next actions. Further, stated that students who use metacognition skills have better achievement than students who don't use metacognition skills. It is because of the skills of metacognition allows students to do the planning, development, and monitor the process of their learning.

Metacognition skills can be improved through some effort, namely through the way in which students are required to observe what students know and what the capitulars observed. Thus, students can be assisted in order to have a complete knowledge of metacognition. Very often happens that the teaching of Metacognition in learning with cognitive strategy (Livingston, 1997). In addition, in the study needs a strategy that empowers Metacognition skills of students.

Relation to the student's achievement, student learning outcomes illustrate the students ' ability in absorbing and understand the material of study taught. Dimyati and Mudjiono (2006: 3) explain the student's achievement is the result of an interaction between learning and teaching. Sudjana (2009) defining student learning outcomes as behavior change as a result of learning. It was concluded, then it can be said that $\mathrm{h}$ acyl study is a very important means of learning process because it is an indicator of the success of the study.

Usman (2000) explains that the indicator of the success of learning is the absorption of students against learning materials and conduct committed individuals and groups in achieving the learning objectives. The student's achievement is emphasized in this research is the result of cognitive learning which has been classified by the Bloom with the revision from Anderson and Krathwohl, including remembering, understanding, 
applying, analyzing, evaluating, and creating.

Research on the relationship between Metacognition skills with cognitive learning outcomes, for example, done by Basith (2010) on the learning strategies Jigsaw the second regression equation is obtained variable, that is, $\mathrm{Y}=$ $1,277 \mathrm{X}-0.488$ with reliability $66.6 \%$ and on the application of learning strategies Think Pair Share (TPS) were obtained the equations the second regression variables, i.e. $\mathrm{Y}=0,956 \mathrm{X}-1.146$ with reliability 82.4\%. In addition, research Arifin (2013) on the application of the strategy of Reciprocal Teaching (RT) regression equation obtained both variables, i.e. $\mathrm{Y}=$ $0,667 X+$ reliability 26,225 31.9\%. Research results Siswati (2014) on each of the implementation strategy Jigsaw, TPS, Cooperative Script, RT, PBMP, and PBMP + TPS also pointed out that there is a relationship between Metacognition skills with cognitive learning outcomes in biology subject matter.

Study of the relationship between Metacognition skills with the results of the study would be better if done in a particular learning model because the model of learning, Metacognition skills, and cognitive learning outcomes can be empowered to students. In this research, the study of the relationship of cooperative learning using model which has the uniqueness of existence for the integration of several aspects, namely Reading, the concept map, and a model Think Pair Share (TPS) or can be shortened to Remap the TPS. This learning refers to learning Remap Coople developed by Zubaidah (2014:6).

\section{Research Methods}

This research uses the draft correlational, where critical thinking skills as predictors and outcomes study as the criterium. The subject of this research is to grade X MIA 2 in SMA Negeri Malang odd semester 2. Metacognition skills measured by r-specific Metacognition skills rubric integrated with essay test developed by Corebima (2009:4). While the results of cognitive learning refer to the cognitive level C2 to C4 revised Bloom's taxonomy by Anderson and Krathwohl.

Research instruments include a syllabus, RPP, Student Worksheet, the observation sheet implementation of syntax Remap TPS, and Metacognition skills rubric. The proposed research hypotheses will be tested with a simple regression correlation analysis technique with 0.05 significance level $(\mathrm{P}<0.05)$ using Metacognition skills data and scores pretest-posttest. Before the test, the hypothesis, do a test of normality test data with Kolmogorov-Smirnov.

\section{Result and Discussion}

The implementation of Remap TPS syntax consistency test results indicates that learning the second regression lines parallel.

Table 1. A Summary Results of The Consistency Test of Syntax Remap TPS

\begin{tabular}{llrrrrr}
\hline & Model & $\begin{array}{c}\text { Sum of } \\
\text { Squares }\end{array}$ & df & $\begin{array}{c}\text { Mean } \\
\text { Square }\end{array}$ & F & Sig. \\
\hline $\mathbf{1}$ & Regression & 17765,175 & 3 & 5921,725 & 2134,551 & 0,000 \\
& b1,b2 & 9,552 & 1 & 9,552 & 3,4433 & 0,072 \\
& b1,b2,b3 & 74,384 & 2 & 37,192 & 13,406 & 0,000 \\
& Residual & 160,905 & 58 & 2,774 & & \\
& Total & 17926,080 & 61 & & & \\
\hline
\end{tabular}


A summary of the results of the test of consistency of syntax Remap TPS on table 1 shows that $F_{\text {count }}$ on test alignment of 3.4433 with the value of the level of significance of 0.050 .072 larger meaning is parallel; Whereas $\mathrm{F}_{\text {count }}$ on a coincident test of significance level value 13.406 of 0.000 smaller than 0.05 meaning not coincide. Based on the analysis results can be said that the learning of biology-based
Remap TPS from beginning to end consistently implemented.

The results of the regression analysis to explain how the relationship between the Metacognition skills with cognitive learning results of students who follow learning to Remap polling stations indicated in Table 2.

Table 2. Summary of Regression Results

\begin{tabular}{ccccc}
\hline Model & R & R Square & $\begin{array}{c}\text { Adjusted R } \\
\text { Square }\end{array}$ & $\begin{array}{c}\text { Std. Error of the } \\
\text { Estimate }\end{array}$ \\
\hline 1 &, $892^{\mathrm{a}}$ &, 796 &, 789 & 2,85444 \\
\hline a. Predictors: (Constant), K_META & & \\
\hline
\end{tabular}

Based on table 2, it can be seen the magnitude of the correlation coefficient (R) of 0,892 with a value of reliability (R2) of 0.796 . Thus, it can be known that Metacognition skills make a contribution amounting to $79.6 \%$ in explaining the achievement of student learning outcomes, while $20.4 \%$ the rest is explained by other factors in the beyond the skills of metacognition. After that, the results of the analysis of ANOVA test followed by to find out whether the predictor can predict criterium significantly.

Table 3. Summary of ANOVA Test

\begin{tabular}{|c|c|c|c|c|c|c|}
\hline \multicolumn{2}{|c|}{ Model } & \multirow{2}{*}{$\frac{\text { Sum of Squares }}{921,369}$} & \multirow[t]{2}{*}{ df } & Mean Square & \multirow{2}{*}{$\begin{array}{l}\mathbf{F} \\
113,082\end{array}$} & \multirow{2}{*}{$\begin{array}{r}\text { Sig. } \\
, 000^{\mathrm{b}}\end{array}$} \\
\hline \multirow[t]{3}{*}{1} & $\begin{array}{l}\text { Regressio } \\
n\end{array}$ & & & 921,369 & & \\
\hline & Residual & 236,287 & 29 & 8,148 & & \\
\hline & Total & 1157,656 & 30 & & & \\
\hline
\end{tabular}

a. Dependent Variable: HB

b. Predictors: (Constant), K_META

A summary of the results of the ANOVA on table 3 , shows the p-value $=0$, 000. $p$-value $>\alpha(\alpha=0.05)$, thus it can be concluded that Metacognition skills capable of predicting the achievement of student learning outcomes. In other languages, it can be said that Metacognition skills have a significant relationship with the achievement of the results of the cognitive learning of students. Furthermore, the results of the analysis of the equation of regression relationship skills in Metacognition with cognitive learning results are contained in table 4.

Table 4. Analyzing of Coefficient Regression

\begin{tabular}{|c|c|c|c|c|c|c|}
\hline & \multirow[t]{2}{*}{ Model } & \multicolumn{2}{|c|}{$\begin{array}{c}\text { Unstandardized } \\
\text { Coefficients }\end{array}$} & \multirow{2}{*}{$\begin{array}{c}\begin{array}{c}\text { Standardized } \\
\text { Coefficients }\end{array} \\
\text { Beta } \\
\end{array}$} & \multirow[t]{2}{*}{$\mathbf{t}$} & \multirow[t]{2}{*}{ Sig. } \\
\hline & & B & Std. Error & & & \\
\hline \multirow[t]{2}{*}{1} & (Constant) & $\begin{array}{r}4,99 \\
5\end{array}$ & 2,594 & & 1,926 &, 064 \\
\hline & K_META &, 885 & 083 & 892 & 10,634 & 000 \\
\hline & endent Vari & & & & & \\
\hline
\end{tabular}




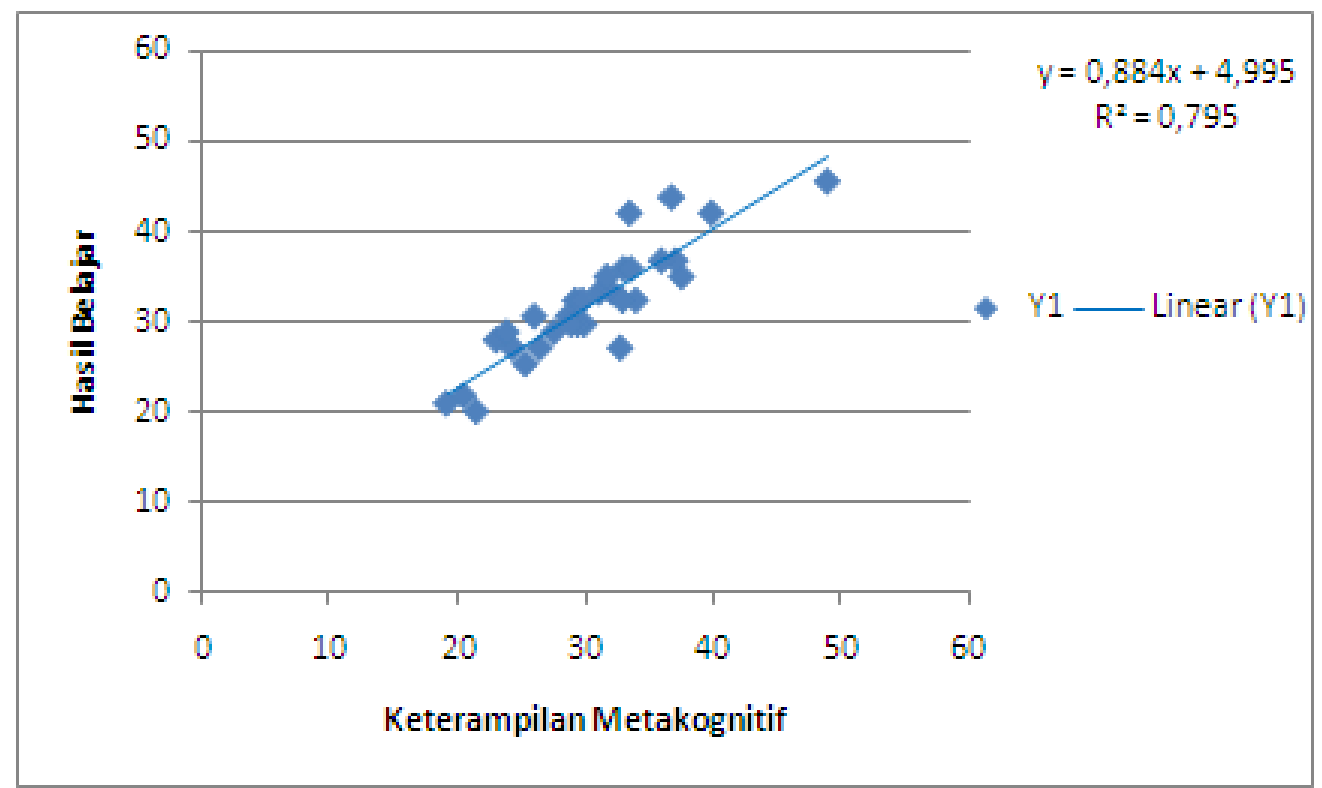

Figure 1. Graph of Relation Metacognition Skills with the results of a Study of students who Follow Learning Remap-TPS

Metacognition Skills is the ability to think about how his studies. Through the ability to think of how learning can be obtained information how the success of their learning so that it can be improved to further learning. In this study, metacognition skills give a donation of $79.6 \%$ of cognitive learning results. It can be said that there is a significant relationship between Metacognition skills with the results of student learning.

Dawson (2008:3) explains that the skill set of competencies is metacognition are related to learning and thinking, as well as the skills needed for active learning, critical thinking, reflective judgments, problem solving, and decision making. The success of metacognition skills in helping students in their learning of the four key metacognition skills, namely planning, monitoring, evaluating, and revising.
Livingston (1997) describes planning is an activity that is done carefully regulating the whole learning process. The behavior plan consists of assigning a sequence of learning objectives, learning, learning strategies, and expectations while learning. Similar to the opinions expressed by Schraw (2006:114) that the stage of planning includes choosing the strategies most appropriate for learning as well as resource allocation. Stage planning also helps students' prediction the difficulties that will be faced, so that students are trying to arrange a way or step in learning in order to obtain optimal learning outcomes.

The next stage are monitoring. This stage refers to a moderate activity on the learning progress. The activities of this monitoring is monitoring during learning activities, for example, can ask himself. Example: "what was I doing?", "what did 
I do right?", "How should I do?", "what information can assist the completion of the task given?", "do I need to do in the different perspectives?", and "Should I set up step based on the existing difficulties? " (Livingston, 1997). Reinforced by Lucangeli, et al. (1998) that the monitoring shows the students aware of the understanding and learning activities are performed.

Furthermore, the evaluating is the evaluation of the learning process of selfassessment that includes the advancement of learning activities. A systematic method of evaluating can help by developing a set of skills and strategies (Livingston, 1997). Lucangeli (1998) reaffirms that the existence of the evaluating phase to assist students in assessing their own ability in learning and be able to compare its capabilities with other friends. In addition, evaluating the process of learning allowing students who have not been right, so being able to think of anything that should be addressed.

Last is revising that is revising the learning process myself which includes modifications to the plans of the previous goals, strategies, and other learning approaches (Livingston, 1997). Based on these opinions, on revising allows students in finding the best alternatives in education based on previous learning experience. Students are also skilled in finding anything inappropriate in his studies, so that time can also use previous goals, strategies, and other learning approaches for the success of their learning.

The above statement was reinforced by Peters (2000) that the skills of Metacognition allow students to develop as independent pupils because it encourages students to become top managers themselves and become appraisers over thought and the lesson of its own. Pierce (2003:1) explains that the more students aware of the thought process while learning, then students will increasingly be able to control goals, personality, as well as attention. Fouche and Lamport (2011:1) add that the activities of learning which refers to Metacognition will improve student learning outcomes.

Pierce (2003:1) describes another component of Metacognition skills based on knowledge of cognition, i.e. declarative, procedural, and conditional. Declarative knowledge is factual information which a person knows, it can be stated whether oral or written. In General, declarative knowledge has the same meaning with factual knowledge. Procedural knowledge is the knowledge how to work on something, how to show the steps of a process. Whereas conditional knowledge is knowledge about when to use procedures, skills, or strategy, and when not; why a procedure works and how in the circumstances; as well as why a procedure is better than the other.

Further, Dawson (2008:7) explains the benefits of Metacognition in learning skills as follows: (1) the student's Metacognition skills taught will have selfregulation so that capable of learning better than students who do not metacognition skills taught; (2) students with skills in Metacognition is a good critical thinkers, problem solvers, decision makers or better than students who do not have good Metacognition skills; (3) training of Metacognition can enhance students ' self-confidence and a sense of responsibility for their own development. The growing confidence and personal responsibility let's generate the motivation to learn; and (4) training of Metacognition can increase the motivation of students to study, so too will impact both to the cognitive learning results of students. 
Metacognition training in learning can be done by giving the assignment to students to write a journal learning any learning is complete. In the learning journal may contain brief explanations of the material to be understood and not yet fully understood, ways of addressing the or strategy will be undertaken related to material that has not been understood, and the plan forward in learning the material. In addition, the training of Metacognition can also be done by giving the opportunity to the students to perform the assessment of yourself, assess and get an assessment from a friend as well as a lecturer.

Upon learning the syntax, Remap TPS accommodate students in the train were critical when reading, make concept maps, and do think-pair-share in order to get the optimal learning outcomes, especially on the cognitive aspect. A teacher or prospective teachers need to consider this aspect of Metacognition skills in order to be empowered in learning with a particular model, so with the hope of Metacognition skills improvement will also be accompanied by increased results cognitive learning.

\section{Conclusions and Suggestions}

The results of this research show that: 1) there is a significant relationship between Metacognition skills with the results of the study of biology students, and Metacognition skills contribution 2) against the results of student learning was $79.6 \%$, while $20.4 \%$ the rest is explained by other factors outside the skill of metacognition.

Based on the results of research that Metacognition skills give great contribution in explaining the results of the study, then teachers need to consider skills empowered students to Metacognition in learning at all subject matter, so that students have good Metacognition skills and will be trained to a high level of thinking that will help in improving the achievement of their learning.

\section{Reference}

Arifin, M.S. (2013). Hubungan Antara Keterampilan Metakognitif terhadap Hasil Belajar Biologi dan Retensi Siswa Kelas $X$ dengan Strategi Reciprocal Teaching di SMA Negeri 1 Lawang. Skripsi tidak diterbitkan. Malang: Universitas Negeri Malang.

Basith, A. (2010). Hubungan Keterampilan Metakognitif dan Hasil Belajar Matapelajaran IPA pada Siswa Kelas IV SD dengan Strategi Pembelajaran Jigsaw dan Think Pair Share (TPS). Skripsi tidak diterbitkan. Malang: Universitas Negeri Malang.

Corebima, A. D. (2009). Metacognitive Skills Measurement Integrated in Achievement Test. Makalah disajikan dalam Third International Conference on Science and Mathematics Education (CosMEd). Malaysia. 10-12 November.

Dawson, T.L. (2008). Metacognition and Learning in Adulthood. Prepared in Response to Tasking from ODNI/CHCO/IC Leadership Development Office. Developmental Testing Service, LLC, Saturday, August 23, 2008. (Online), (https://dts.lectica.org/PDF/Metaco gnition.pdf), diakses 11 Desember 2014.

Dimyati dan Mudjiono. (2006). Belajar dan Pembelajaran. Jakarta: Rineka Cipta. 
Fouche, J. dan Lamport, M. A. (2011). Do Metacognitive Strategies Improve Student Achievement in Secondary Science Classrooms?. Christian Perspectives in Education, vol. 4(2), hal.1-25.

Imel, S. (2002). Metacognitive Skill For Adult Learning. ERIC, Educational Resources Information Centre Trends And Issues Alert, vol.39, hal.1-5.

Livingston, J. A. (1997). Metacognition: an Overview. (Online), (http://gse.buffalo.edu/fas/shuell/ce p564/metacog.htm), diakses 3 November 2014

Lucangeli, D., Carnoldi, C., dan Tellarini, M. (1998). Metacognition and Learning Disabilities in Mathematics. Advances in Learning and Behavioral Disabilities, hal.219-285.

Peters, M. A. (2000). Does Contructivist Epistemology Have a Place in Nurse Education?. Journal of Nursing Education, vol.39(4), hal.166-72.

Pierce, W. (2003). Metacognition: Study Strategies, Monitoring, and Motivation. A Greatly Expanded Text Version of a Workshop Presented November 17, 2004, at Prince George's Community College. (Online), (http://academic.pg.cc.md.us/ wPi erce/MCCCTR/metacognition.htm ), diakses, 2 November 2014.

Schraw, G., Crippen, K. J., dan Hartley, K. (2006). Promoting Selfregulation in Science Education: Metacognition as Part of a Broader Perspective on Learning. Research in Science Education, vol.36, hal.111-139.

Slavin, R. E. (2011). Cooperative Learning: Teori Riset dan Praktik. Bandung: Nusa Media.
Sudjana. 2009. Penilaian Hasil Proses Belajar Mengajar. Jakarta: Rineka Cipta.

Usman, M. U. (2000). Menjadi guru Profesional. Bandung: Remaja Rosdakarya.

Zubaidah, S. (2014). Pemberdayaan Keterampilan Penemuan dalam Scientific Approach melalui Pembelajaran Berbasis Remap Coople. Makalah disajikan pada Seminar Nasional XI bertema Biologi, Sains, Lingkungan, dan Pembelajarannya di Universitas Sebelas Maret pada tanggal 7 Juni 2014. 
Jurnal Pena Sains Vol. 5, No. 1, April 2018

p-ISSN: 2407-2311

e-ISSN: 2527-7634 